\title{
The Addition of Honey Bee to the Feed to Increase the Growth of White Snapper Seeds (Lates calcarifer)
}

\author{
Linayati Linayati ${ }^{1 *}$, Bramantiar Rizkyansyah $^{1}$, Tri Yusufi Mardiana ${ }^{1}$ and Muhammad \\ Zulkham Yahya ${ }^{1}$ \\ ${ }^{1}$ Aquaculture Department, Fisheries Faculty, Pekalongan University, Jl. Sriwijaya No 3 Pekalongan, \\ Central Java 51119, Indonesia
}

*Correspondence :

pattyana95ina@yahoo.co.id

Received : 2021-05-21

Accepted : 2021-08-29

Keywords :

Honey bee, White snapper seeds, Growth

\begin{abstract}
The purpose of this study was to determine the effect of adding honey to the feed for growth and the best dosage for the growth of white snapper seeds. The white snapper seeds used have an average weight of $\pm 2.5 \mathrm{~g}$ /fish. This study used an experimental method with a Completely Randomized Design (CRD). The experiment was carried out in 5 (five) treatments and each treatment had 3 (three) repetitions. The treatment consisted of adding honey to the feed with a treatment dose of (A) $0 \mathrm{ml} / \mathrm{kg}$ of feed, (B) $50 \mathrm{ml} / \mathrm{kg}$ of feed, (C) $100 \mathrm{ml} / \mathrm{kg}$ of feed, (D) $150 \mathrm{ml} / \mathrm{kg}$ of feed and (E) 200 $\mathrm{ml} / \mathrm{kg}$ of feed. The results indicated that the addition of honey to the feed had a significant effect on the growth of white snapper seeds. The best dose of honey is at a dose of $200 \mathrm{ml} / \mathrm{kg}$ which has the best effect on fish growth. The condition of water quality during the study was in a suitable range for the life of white snapper seeds.
\end{abstract}

\section{INTRODUCTION}

White snapper (Lates calcarifer) is a demersal fish that is one of the leading aquaculture commodities in Indonesia, because of its high economic value around IDR $75.000-80.000 / \mathrm{Kg}$ (Yaqin et al., 2018) and also has relatively fast growth. According to Rayes et al. (2013), white snappers have a daily growth rate of approximately $0.51 \% /$ day. Its survival rate at $86 \%$, and they are easy to adapt to the cultivation environment. According to Purba et al. (2016), white snapper is a type of seawater fish that contains omega-3, the protein content of this fish is about $20 \%$, and has a fat content of $5 \%$. It caused the market demand for this fish quite high.

White snapper is one of the potential aquaculture products due to continuous import demand on the international market. According to FAO (2021), the import of Seabass reached 24.000 tons in 2020. The high market demand shall be balanced with fast and efficient cultivation to fulfill this demand, and one of the most important factors in cultivation is feed. Dalimunthe (2019) explains that in cultivation activities, feed cost contribution may reach $80-90 \%$ of the total production cost. Moreover, Ghomi et al. (2012) stated that feed manipulation can be a strategy to optimize growth and according to Prihaningrum et al. (2015), the dose of artificial feeding in the larval phase is $7-10 \%$ of the biomass and is given 3-5 times/day.

Recently, several studies have focused on the improvement of the welfare and sustainability of animal 
husbandry in aquaculture by optimizing fish feeds. Such utilization of these feeds may be achieved by adding honeybee. Previous research by Islamiyah et al. (2018) stated that adding the honey bee to the feed affected the growth of milkfish. The honeybee is defined as a thick, sweet liquid made by bees from flower nectar or a sweet liquid produced by parts other than flowers. Nectar is a very complex substance produced by plant glands in the form of a sugar solution with varying concentrations ranging from $5-70 \%$. The honey bee is a complex compound.

According to Afroz et al. (2016), the nutrients contained in honey bees include carbohydrates, proteins, amino acids, phenols, vitamins, and minerals, According to Bagdanov (2016), the composition of honey bees are carbohydrate $79 \%$, amino acids, and protein, $0,3 \%$. This complex compound is needed, especially to spur growth. In addition, honey also contains enzymes, as stated by Putra et al. (2018), that the important enzymes contained in honey are diastase, invertase, glucose oxidase, peroxidase, and protease. The purpose of this study was to determine the effect of adding honey bees as a supplement has an important role in increasing the growth of white snapper seeds.

\section{METHODOLOGY}

\section{Place and Time}

The study was conducted on December $10^{\text {th }}, 2020$ - January $10^{\text {th, }} 2021$ at the Brackish and Marine Water Laboratory, Faculty of Fisheries, Pekalongan University.

\section{Research Materials}

The test fish used was white snapper (Lates calcarifer) seed obtained from the Center for Brackish Water Cultivation Fisheries, Situbondo, East Java with an average weight of $\pm 2.5 \mathrm{~g} /$ fish. Fish are reared for 30 days with a stocking density of 1 fish/L (Walusi et al., 2019). The vessel used is a plastic jar with a water volume of 4 liters. The water medium used is seawater with a salinity of 34 ppt. The seeding activity is carried out in the afternoon and first acclimatized for 3 days (Jaya et al., 2013).

The test feed, feed used was in the form of pellets with the size of 4.1-4.3 mm and the addition of honey with a certain dose. The tools and materials used are aquariums, weight digital scales, aerators stone, spray bottles, filter foam, white snapper seeds, seawater, honey bee, artificial feed, and distilled water (aqua dest).

\section{Research Design}

The study used a Completely Randomized Design (CRD) with 5 treatments and 3 repetitions. The dosage used is as follows: Treatment A (feed +0 $\mathrm{ml} / \mathrm{kg}$ of feed); Treatment B (feed $+50 \mathrm{ml}$ honey bee/kg of feed); Treatment C (feed $+100 \mathrm{ml}$ honey bee/ $\mathrm{kg}$ of feed); Treatment D (feed $+150 \mathrm{ml}$ honey bee/ $\mathrm{kg}$ of feed); and Treatment E (feed +200 $\mathrm{ml}$ honey bee/ $\mathrm{kg}$ of feed).

Determination of dosage refers to the study of Arifin and Rumondang (2017), which states that the best dose of adding honey in feed is $150 \mathrm{ml} / \mathrm{kg}$ of feed.

\section{Work Procedure \\ Feed Production}

The feed used is in the form of commercial pellets measuring 4.1-4.3 mm which are adjusted to the fish mouth opening. The feed is then sprayed with a honey solution that has been diluted with distilled water (aqua dest) about $100 \mathrm{ml}$ for each treatment. The spraying was done by turning the feed (pellets). Furthermore, the pellets are aerated for 15-20 minutes so that they are dry and not moldy (Arifin and Rumondang, 2017).

\section{Maintenance and Feeding}

Maintenance of fish seeds is carried out for 30 days, with a percentage of feed as much as $7 \%$ of the weight of the tested fish biomass and given 3-5 times a day (Prihaningrum et al., 2015). The protein content given to support seed growth in 
artificial feed is not less than $40 \%$. The feed given shall be sufficient since lack of feed will result in cannibalism in white snapper.

\section{Absolute Weight Growth}

Absolute weight growth is calculated using the formula from Effendi (1979) as follows:

$\mathrm{W}=\mathrm{Wt}-\mathrm{Wo}$

Where:

W : Growth absolute weight (grams)

$\mathrm{W}_{\mathrm{t}}$ : Final average weight (grams)

$\mathrm{W}_{\mathrm{o}}:$ Initial average weight (grams)

\section{Survival Rate}

The calculation of the survival rate is calculated as follows:

$\mathrm{SR}=\frac{\mathrm{Nt}}{\mathrm{No}} \times 100 \%$

Where :

$\mathrm{N}_{\mathrm{t}}$ : Number of live fish at the end of the study

$\mathrm{N}_{\mathrm{o}}$ : Number of fish at the beginning of the study

\section{Data Analysis}

Data analysis using ANOVA, but first the normality and homogeneity tests were carried out. The normality test was carried out using the Liliefors test (Nasoetion and Barizi, 1983), carried out to determine the growth rate in each treatment is normally distributed. The homogeneity test uses the Barlett test (Sudjana, 1996) to determine whether the data is homogeneous or not. Furthermore, variance analysis (ANOVA) was carried out, if the variance test was obtained significantly different then the Tukey test was carried out, while the water quality data were analyzed descriptively.

\section{RESULTS AND DISCUSSION Results of Absolute Weight Growth}

The results of observations of absolute weight growth from this study are presented in graphical form in Figure 1 below.

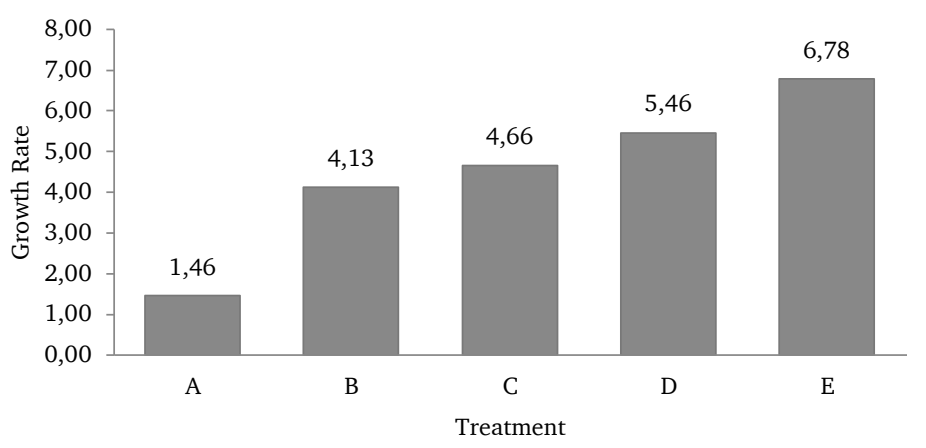

Figure 1. Growth chart.

Based on graph 1, it can be seen that the growth of white snapper seeds which have the highest value is in treatment $\mathrm{E}$ with an average value of 6.78 gr while the lowest biomass growth was obtained by treatment A with a mean value of 1.46 gr. The results of the normality test obtained indicate that the data is normally distributed, then followed by the homogeneity test and produce homogeneous data so that the data can be analyzed for variance (ANOVA).

Based on the analysis of variance $F$ count (24.464) $>$ from the $F$ table value $5 \%$ and $1 \%$ (3.478 and 5.035), this means that the data resulting from the addition of honey to the feed with different doses for the growth of white snapper seeds have a significant effect on the growth of white snapper seeds (Table 1). 
Table 1. Analyzed for variance.

\begin{tabular}{llrrrrr}
\hline \multirow{2}{*}{ SK } & \multirow{2}{*}{ DB } & \multirow{2}{*}{ JK } & \multirow{2}{*}{ KT } & F Count & \multicolumn{2}{c}{ F TABLE } \\
\cline { 6 - 7 } & & & & & $5 \%$ & $1 \%$ \\
\hline Treatments & 4 & 36,194 & 9,048 & & 3,478 & 5,035 \\
Error & 10 & 3,6988 & 0,369 & & & \\
Total & 14 & 39,893 & & & & \\
\hline
\end{tabular}

\section{Survival Rate}

Table 2. The survival rate of fish.

\begin{tabular}{lccccl}
\hline & A & B & C & D & E \\
\hline No & 12 & 12 & 12 & 12 & 12 \\
Nt & 10 & 12 & 12 & 12 & 12 \\
SR & $83 \%$ & $100 \%$ & $100 \%$ & $100 \%$ & $100 \%$ \\
\hline
\end{tabular}

Note $: \mathrm{SR}=$ Survival Rate, $\mathrm{Nt}=$ Number of live fish at the end of the study, No $=$ Number of fish at the beginning of the study.

From Table 2, it was found that the observation results for each treatment, the survival rate of the white snapper seeds on treatments B, C, D, and E showed very good results, it is $100 \%$, whereas treatment A only got a percentage of $83 \%$.
Based on the analysis of variance (Table 3), that F count (1) < from the F table value $5 \%(5,19216)$. This means that the data resulting from the addition of honey to the feed with different doses have no significant effect on the survival rate of White snapper seeds.

Table 3. The analyzed variance of SR.

\begin{tabular}{lllllll}
\hline Source of Variation & SS & df & MS & F & P-value & F Table \\
\hline Treatment & 1.6 & 4 & 0.4 & 1 & 0.4856 & 5.19216 \\
Error & 2 & 5 & 0.4 & & & \\
Total & 3.6 & 9 & & & & \\
\hline
\end{tabular}

Growth is an increase in size within a certain time with the same intervals, for example, one week, ten days, two weeks, and one month (Fujaya, 2004). Fish growth may occur if the number of feed nutrients digested and absorbed by the fish is greater than the amount needed for body maintenance.

According to Putra et al. (2018), honey contains diastase, invertase, glucose oxidase, peroxidases, and protease enzymes. These enzymes would help hydrolyze feed nutrients (complex molecules), such as breaking down carbohydrates, proteins, and fats into simpler molecules that will facilitate the process of digestion and absorption in the digestive tract of fish (Putra, 2010).

The growth of white snapper seed biomass with the highest result was shown in treatment $\mathrm{E}$ resulting in average biomass of 6.78 gr. A higher dose of the honey bee would increase the number of enzymes and nutrition on it. This condition would bring a positive impact to the total digestion and the intake of nutrients that are absorbed and utilized by the fish body in the metabolic process. Furthermore, high content of nutrition in honey bees such as carbohydrates, lipid, vitamins could promote fish growth and increasing immunity. Carbohydrates as a source of energy for metabolism, include energy for growth, life, and food intake. According to Amel et al. (2014), honey incorporation into the diet improves the growth rate in tilapia.

The average weight of biomass obtained after treatment E then followed by treatment $\mathrm{D}$ resulted in an average biomass value of $5.46 \mathrm{~g}$ treatment $\mathrm{C}$ had a mean biomass value of $4.66 \mathrm{~g}$, while treatment $\mathrm{B}$ produced a mean biomass value of $4.13 \mathrm{~g}$. The lowest value of 
biomass is in treatment $\mathrm{A}$ of $1.46 \mathrm{~g}$. The difference in biomass values is due to different doses of honey added to the feed, thus affecting the number of enzymes contained in the feed. In the study of Arifin and Rumondang (2017), honey bee also affects the growth of catfish, where the higher the dose of honey given then the higher the fish growth.

\section{Survival Rate}

The survival rate for white snapper seeds was the same in treatment $\mathrm{B}, \mathrm{C}, \mathrm{D}$, and $E$ with a $100 \%$ survival rate, which means that the white snapper seeds did not experience mortality during the maintenance time. These results are analyzed descriptively. The $100 \%$ life percentage in treatment $\mathrm{B}, \mathrm{C}, \mathrm{D}$, and $\mathrm{E}$ may be caused by feed added with honey bee contains good complex compounds such as antioxidants which may increase body resistance. This is following the opinion of Afroz et al. (2016), which states that honey contains complex compounds (chemical and biochemical) including sugars (carbohydrates), proteins, amino acids, phenols, vitamins, minerals, and antioxidants. Treatment A showed the lowest percentage of seed life, it is $83 \%$.
This is due to the absence of protection from stress by honey. Latumahina et al. (2011) stated that honey bees can inhibit oxidative stress with their antioxidant content. Honey Bee also can protect fish from Aeromonas hydrophila infection by up to 93\% (El-Asely et al., 2014). Moreover, the presence of antioxidants could prevent fish from aquatic animal disease and increase their performance (Choobkar et al., 2017).

The results of temperature observations during the study showed a temperature range of $28-30^{\circ} \mathrm{C}$. This is still suitable for the growth of white snapper seeds, with a temperature range of 27$29^{\circ} \mathrm{C}$ (Wirasakti et al., 2021). In observing $\mathrm{pH}$ during the study, it was found that a $\mathrm{pH}$ range of 7.0-7.5, the $\mathrm{pH}$ value is considered to be supportive for the life of white snapper seeds as stated by Windarto et al. (2019). Salinity values of 33-34 ppt are still in the appropriate range. The dissolved oxygen (DO) in water ranges from 5.5 to $7.0 \mathrm{ppm}$ within the appropriate range according to Windarto et al. (2019).

The value of water quality in this study generally supports the life of white snapper seeds.

Table 4. Value of water quality.

\begin{tabular}{llll}
\hline Parameter & Observed value & Standard value & Reference \\
\hline Temperature $\left({ }^{\circ} \mathrm{C}\right)$ & $28-30$ & $27-29$ & Wirasakti et al. $(2021)$ \\
Salinity(ppt) & $33-34$ & $32-34$ & Nurmasyitah et al. $(2018)$ \\
DO $(\mathrm{ppm})$ & $5,2-7,0$ & $4 \leq$ & Windarto et al. $(2019)$ \\
pH & $7,0-7,5$ & $7,0-7,8$ & Windarto et al. $(2019)$ \\
\hline
\end{tabular}

\section{CONCLUSION}

Based on the results of the study that has been done, it can be concluded that the addition of honey to the feed with different doses for the growth of white snapper seeds has a very significant effect on the growth of white snapper seeds.

The best growth was obtained in treatment E with a dose of $200 \mathrm{ml} / \mathrm{kg}$ of feed with a biomass value of $6.78 \mathrm{gr}$ and the water quality observed during the study was considered good for white snapper seeds since it was following the existing literature, with a temperature range of $28-30^{\circ} \mathrm{C}, \mathrm{pH} 7.0-8.5$, DO

\section{ACKNOWLEDGMENT}

This study was funded by the Faculty of Fisheries, Pekalongan University. I want to express my appreciation to fellow lecturers, students, and all who have supported the publication of this article.

\section{REFERENCES}

Afroz, R., Tanvir, E.M., Zheng, W. and Little, P.J., 2016. Molecular 
pharmacology of honey. Journal of Clinical and Experimental Pharmacology, 6(3), pp.1-13. http:/ /dx.doi.org/10.4172/2161-1459.10 00212

Amel, A., Hickner, M. and Eli, Y.E., 2014. Cross-linked anion exchange membranes for AEMFC. ECS Transactions, 64(3), p.1229. https:/ /doi.org/10.1149/06403.1229ecst

Arifin, Z. and Rumondang, 2017. Pengaruh pemberian suplemen madu pada pakan terhadap pertumbuhan dan FCR ikan lele dumbo (Clarias gariepinus). Fisherina: Jurnal Penelitian Budidaya Perairan, 1(1), pp.1-10. http://jurnal.una.ac.id/index.php/f isherina/article/view/176

Bagdanov, S., 2016. Honey Composition: The Honey Book, Chapter 5. pp.1-11. https://www.researchgate.net/publ ication/304011775

Choobkar, N., Kakoolaki, S., Mohammadi, F. and Rezaeimanesh, M., 2017. The effect of dietary propolis and pollen extracts on growth performance and haematological responses of rainbow trout (Onchorhynchus mykiss). Iranian Journal of Aquatic Animal Health, 3(1), pp.16-25. http://dx.doi.org/10.18869/acadp ub.ijaah.3.1.16

Dalimunthe, A.S., 2019. Pengaruh pemberian pakan dengan kadar metionin berbeda terhadap pertumbuhan ikan kakap putih (Lates calcarifer) di bak terkontrol. Bachelor Thesis. Faculty of Agriculture, Universitas Sriwijaya, Palembang. p.35.

Effendi, M.I., 1997. Biologi perikanan. Yayasan Pustaka Nusantara, Yogyakarta. p.257.

El-Asely, A.M., Abass, A.A. and Austin, B., 2014. Honey bee pollen improves growth, immunity and protection of Nile tilapia (Oreochromis niloticus) against infection with Aeromonas hydrophila. Fish \& Shellfish Immunology, 40(2), pp.500-506. https://doi.org/10.1016/j.fsi.2014. 07.017

FAO, 2021. GLOBEFISH Highlights - A quartely update on world seafood markets $1^{\text {st }}$ issue 2021 JanuarySeptember $2020 \quad$ Statistics. Globefish Highlights No. 1-2021, pp.36-38. https://doi.org/10.4060/ cb4129en

Fujaya, Y., 2004. Fisiologi ikan dasar pengembangan teknik perikanan. Rineka Putra, Jakarta.

Ghomi, M.R., Shahriari, R., Langroudi, H.F., Nikoo, M. and von Elert, E., 2012. Effects of exogenous dietary enzyme on growth, body composition, and fatty acid Profiles of cultured great sturgeon (Huso huso) fingerlings. Aquaculture International, 20, pp.249-254. https://doi.org/10.1007/s10499-01 1-9453-9

Islamiyah, D., Rachmawati, D. and Susilowati, T., 2018. Pengaruh penambahan madu pada pakan buatan dengan dosis yang berbeda terhadap performa laju pertumbuhan relatif, efisiensi pemanfaatan pakan dan kelulushidupan ikan bandeng (Chanos chanos). Pena Akuatika, Jurnal Ilmiah Perikanan dan Kelautan, 17(2), pp.19-33. http://d x.doi.org/10.31941/penaakuatika.v $17 \mathrm{i} 2.658$

Jaya, B., Agustriani, F. and Isnaini, 2013. Laju pertumbuhan dan tingkat kelangsungan hidup benih kakap putih (Lates calcarifer, Bloch) dengan pemberian pakan yang berbeda. Maspari Journal, Marine Science Research, 5(1), pp.56-63. https://doi.org/10.36706/maspari. v5i1.1299

Latumahina, G.J., Kakisina, P. and Moniharapon, M., 2011. Peran madu sebagai antioksidan dalam mencegah kerusakan pankreas mencit (Mus musculus) terpapar asap rokok kretek. Molucca Medica, 4(1), pp.106-116. https://ejournal. 
unpatti.ac.id/ppr_iteminfo_lnk.php ?id $=578$

Nasoetion, A.H. and Barizi, 1983. Metode statistik untuk penarikan kesimpulan. PT. Gramedia Pustaka, Jakarta. p.223.

Nurmasyitah, Defira, C.N. and Hasanuddin, 2018. Different natural feeding conducted the survival rate of white snapper fish larvae (Lates calcarifer). Jurnal Ilmiah Mahasiswa Kelautan Perikanan Unsyiah, 3(1), pp.56-65. http://jim.unsyiah.ac.id/ fkp/article/view/8533

Prihaningrum, A., Aditya, T.W. and Saputra, Y., 2015. Petunjuk teknis budidaya ikan kakap putih (Lates calcalifer, Bloch) di karamba jaring apung. Balai Besar Perikanan Budidaya Laut, Lampung, p.66.

Purba, E.P., Ilza, M. and Leksono, T., 2016. Studi penerimaan konsumen terhadap steak (fillet) ikan kakap putih flavor asap. Jurnal Online Mahasiswa Fakultas Perikanan dan Ilmu Kelautan, Universitas Riau, 3(1), pp.1-11. https://jom.unri.ac.i d/index.php/JOMFAPERIKA/article /view/12055

Putra, A.N., 2010. Kajian probiotik dan sinbiotik untuk meningkatkan kinerja pertumbuhan ikan nila (Oreochromis niloticus). Master Thesis. Program Pasca Sarjana. Institut Pertanian Bogor, Bogor. p.91.

Putra, H.S., Astuti, W. and Kartika, R., 2018. Activities of amylase, protease and lipase from Honey Trigono sp., Apis mellifera and Apis dorsata. Jurnal Kimia Mulawarman, 16(1), pp.27-31. https://doi.org/10.30872 /jkm.v16i1.433

Rayes, R.D., Sutresna, I.W., Diniarti, N., and Supii, A.I., 2013. Pengaruh perubahan salinitas terhadap pertumbuhan dan sintasan ikan kakap putih (Lates calcarifer Bloch). Jurnal Kelautan, 6(1), pp.47-56. https://doi.org/10.21107/jk.v6i1.8 32
Sudjana, 1996. Metode statistika, edisi keenam. Tarsito, Bandung. p.503.

Walusi, R., Nasution, S. and Zulkifli, 2019. The effect of stocking densities on growth and survival of Barramundi (Lates calcarifer Bloch, 1790). Jurnal Online Mahasiswa Fakultas Perikanan dan Kelautan Universitas Riau, 6(2), pp.1-12. https://jom.unr i.ac.id/index.php/JOMFAPERIKA/a rticle/view/27108

Windarto, S., Hastuti, S., Subandiyono, Nugroho, R.A. and Sarjito, 2019. Performa pertumbuhan ikan kakap putih (Lates calcarifer Bloch, 1790) yang dibudidayakan dengan sistem keramba jaring apung (KJA). Jurnal Sains Akuakultur Tropis, 3(1), pp.56-60. https://doi.org/10.1471 0/sat.v3i1.4195

Wirasakti, P., Diniarti, N. and Astriana, B.H., 2021. The effect of different colors of rearing containers on survival rate and growth of the Barramundi juvenile (Lates calcarifer). Jurnal Perikanan, 11(1), pp. 98-110. https://doi.org/10.293 03/jp.v11i1.178

Yaqin, M.A., Santoso, L. and Saputra, S., 2018. Pengaruh pemberian pakan dengan kadar protein berbeda terhadap performa pertumbuhan ikan kakap putih (Lates calcarifer) di keramba jaring apung. Jurnal Sains Teknologi Akuakultur, 2(1), pp.1219. https://jsta.aquasiana.org/inde x.php/jmai/article/view/39/42 